\title{
THE IMMUNOLOGICAL FEATURES AND PATHOPHYSIOLOGY OF OCULAR CICATRICIAL PEMPHIGOID
}

\author{
MARK J. ELDER ${ }^{1,2}$ and SUSAN LIGHTMAN ${ }^{1,2}$ \\ London
}

\begin{abstract}
SUMMARY
Ocular cicatricial pemphigoid is an uncommon but severe and potentially blinding systemic disease. It shares many pathophysiological features with the other bullous skin diseases such as dermatitis herpetiformis, bullous pemphigoid and pemphigus vulgaris. All of these diseases have circulating antibodies that bind to the basement membrane of mucous membranes. The individual diseases differ by each having a specific component of the basement membrane complex as its antigen. In acute ocular cicatricial pemphigoid, the conjunctiva is infiltrated with neutrophils, macrophages, Langerhans cells and CD8+ and CD4+ T-cells while in the chronic disease the conjunctiva is infiltrated mainly by CD8+ T-cells. There is evidence of activation of these T-cells as CD4+ cells as shown by expression of the interleukin-2 receptor and increased expression of major histocompatibility class II antigens within the tissue. The aetiology of the fibrosis is unknown but increased amounts of several fibrogenic growth factors are demonstrable by immunohistochemistry.
\end{abstract}

Clinically, cicatrising conjunctivitis may range from asymptomatic subtarsal or canthal fibrosis to a complete obliteration of the fornices with total keratinisation of the ocular surface. ${ }^{1}$ The cicatrisiation may have a wide range of aetiologies including physical, chemical, pharmaceutical, infectious, inflammatory and immune stimuli. ' This cicatrisation may impair corneal function by a variety of mechanisms. These include a dysfunction in any of the three tear film layers, abnormal lid-globe contact or movement, trichiasis, exposure, and a predisposition to blepharitis and keratitis. This paper summarises current

From: 'Moorfields Eye Hospital, London; ${ }^{2}$ Institute of Ophthalmology, London, UK.

Correspondence to: Mark Elder, Moorfields Eye Hospital, City Road, London EC1V 2PD, UK.

Eye (1994) 8, 196-199 C 1994 Royal College of Ophthalmologists knowledge about the immune basis and pathophysiology of ocular cicatricial pemphigoid.

\section{BULLOUS SKIN DISEASES}

All of the bullous skin diseases may be associated with cicatricial conjunctival changes but they are uncommon, mild and frequently asymptomatic. These diseases include dermatitis herpetiformis, ${ }^{1,2}$ epidermolysis bullosa, ${ }^{1,4-10}$ pemphigus vulgarus ${ }^{1,3,11-16}$ and bullous pemphigoid. ${ }^{17-22}$ As a family of diseases, they all have circulating antibodies to skin and mucous membrane basement membrane. Antibodies and complement are bound to the basement membrane of lesional and non-lesional skin. However, the diseases differ by each having a unique component of the basement membrane as its antigen (Table I). The exceptions to this are that dermatitis herpetiformis does not have a circulating antibody ${ }^{2}$ and the antigen in pemphigus vulgaris is the intercellular cement substance..$^{12,13.15}$ The disease with the most severe ocular consequences is ocular cicatricial pemphigoid. ${ }^{\prime}$

\section{CLINICAL FEATURES OF OCULAR CICATRICIAL PEMPHIGOID}

Ocular cicatricial pemphigoid (OCP) affects elderly patients, with a mean age at presentation of 58-69 years. ${ }^{23-26}$ Ocular involvement occurs in $66-77 \%$ of cases. ${ }^{23-27}$ In an ophthalmic series, skin lesions were present in $9 \%$ of cases. ${ }^{25}$ Other mucous membrane involvement included the mouth (15\%), nose (12\%) and oeosphagus $(9 \%){ }^{25}$ There is an association with HLADQw7 (DQB $1 * 0301)^{28}$ and affected patients have a fourfold increase in the prevalence of other autoimmune diseases $(p<0.01)$ - mainly rheumatoid arthritis but also systemic lupus erythematosus and polyarteritis nodosa. ${ }^{25}$

The disease may be acute and associated with inflammation, or chronic and not associated with inflammation. 
Table I. The immune-related cicatrising conjunctivitides

\begin{tabular}{ll}
\hline Disease & Antibody binding site \\
\hline Ocular cicatricial pemphigoid & Lamina lucida of BMZ \\
Dermatitis herpetiformis & Sublamina densa region of BMZ \\
Epidermolysis bullosa & Type VII procollagen in BMZ \\
Pemphigus vulgarus & Intercellular cement substance \\
Bullous pemphigoid & 220 kDa glycoprotein in BMZ \\
Stevens-Johnson syndrome & Blood vessel wall \\
\hline
\end{tabular}

BMZ, basement membrane zone.

Progression of the ocular cicatrisation occurs in $75 \%$ of patients not receiving treatment. ${ }^{26,29}$ The cicatrisation may occur as a gradual event not associated with inflammation or in a stepwise manner during periods of acute inflammation. ${ }^{24,30,31}$ Surgically induced inflammation can cause rapid progression, such as may occur with entropion correction or cryotherapy. ${ }^{26,30-33}$

Clinically, the sequence of progression is usually that of progressive shrinkage of the conjunctiva with symblepharon, development of cicatricial entropion of both upper and lower lids, trichiasis, obliteration of the fornices, ocular surface keratinisation, diminution of the tear film and eventual keratopathy. At any point there may be an exacerbation of conjunctival inflammation.

\section{IMMUNE FEATURES IN OCULAR CICATRICIAL PEMPHIGOID}

Circulating antibodies to conjunctival basement mem-

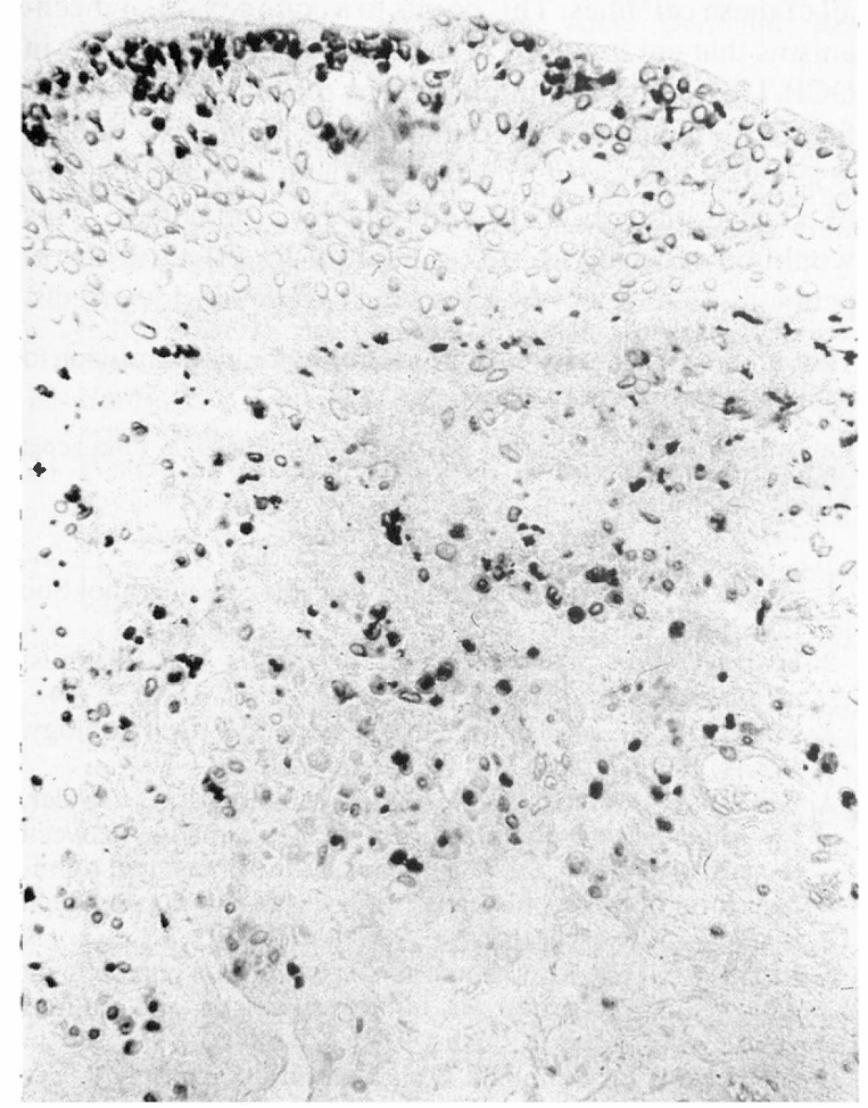

Fig. 1. Acute ocular cicatricial pemphigoid showing intense infiltration with neutrophils in the conjunctival stroma and epithelium. $\times 125$. (Courtesy of Dr W. Bernauer.) brane are detected in about $50 \%$ of patients. ${ }^{30,32,34-38}$ This antibody is directed against basement membrane antigens of $230 \mathrm{kDa}$ and/or $160-180 \mathrm{kDa}$. There is some crossreactivity with bullous pemphigoid antigen. ${ }^{18,33,39} \mathrm{Immu}-$ noglobulins $\mathrm{G}$ and $\mathrm{A}$ and complement are bound to conjunctival basement membrane in up to $67 \%$ of cases. $^{25,33,36,40}$ The binding is strictly linear and is along the superficial and deep aspects of the lamina lucida. ${ }^{18}$ Various components of complement are bound to the basement membrane including C1q, C3, C4 and properdin, ${ }^{30,31,39,40}$ and complement may be activated via both the classical and the alternative pathway. ${ }^{41}$ Lysis of the desmosomal attachments of the basal layer of the epithelium causes the subepithelial bullae, which may be clinically manifest, especially involving the skin or mouth. ${ }^{42,43}$

Further evidence for an autoimmune basis of the disease comes from the development of an animal model in rabbits. ${ }^{45}$ The injection of a monoclonal antibody into basement membrane of conjunctival epithelium (MAb63) causes conjunctival inflammation, neutrophil infiltration and basement membrane deposition of IgG in a pattern similar to that seen in acute OCP.

Immunohistochemical studies ${ }^{25,33,40,44}$ have shown that the acute, ulcerative phase affects both the conjunctival epithelium and the substantia propria. The stromal
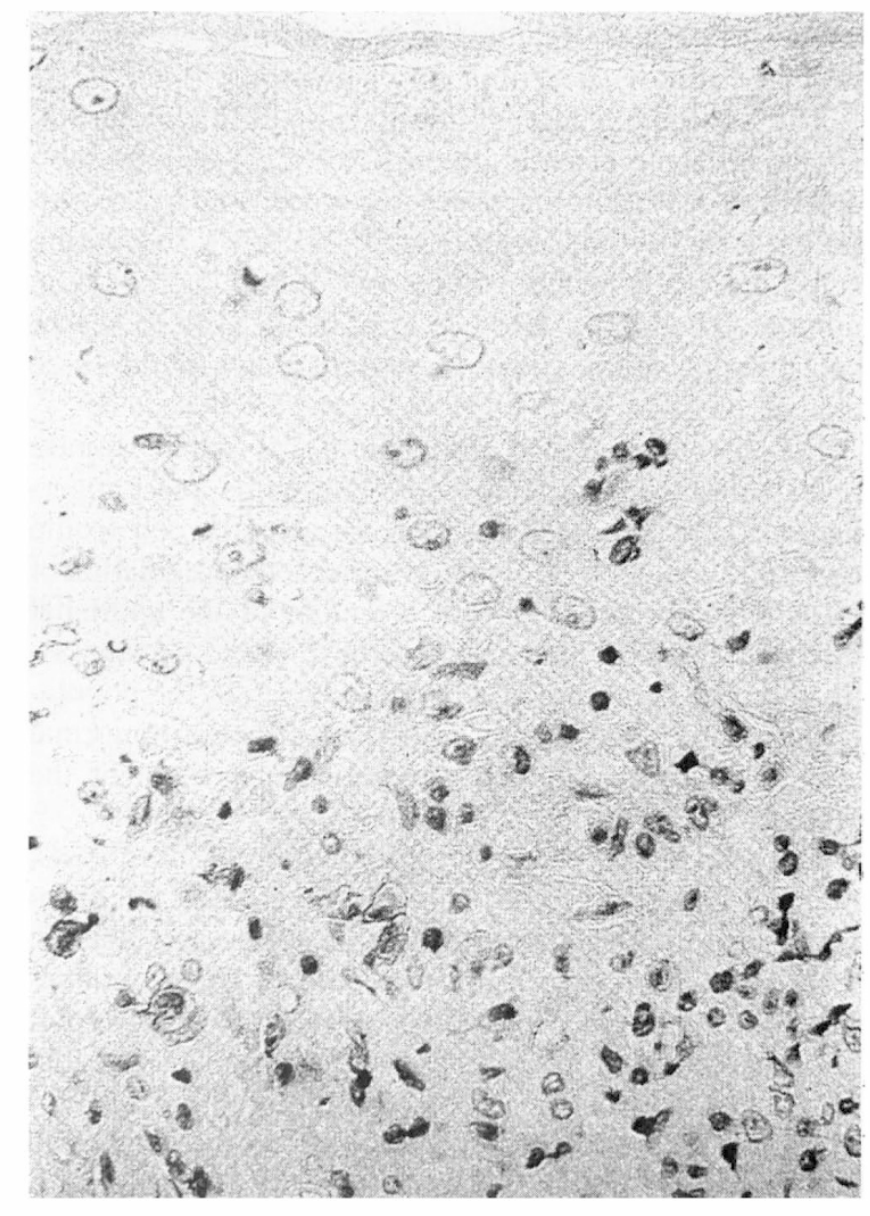

Fig. 2. Subacute ocular cicatricial pemphigoid stromal conjunctiva showing T-cells staining positive for interleukin 2 receptor suggesting activation. $\times 500$. (Courtesy of $\mathrm{Dr} W$. Bernauer.) 


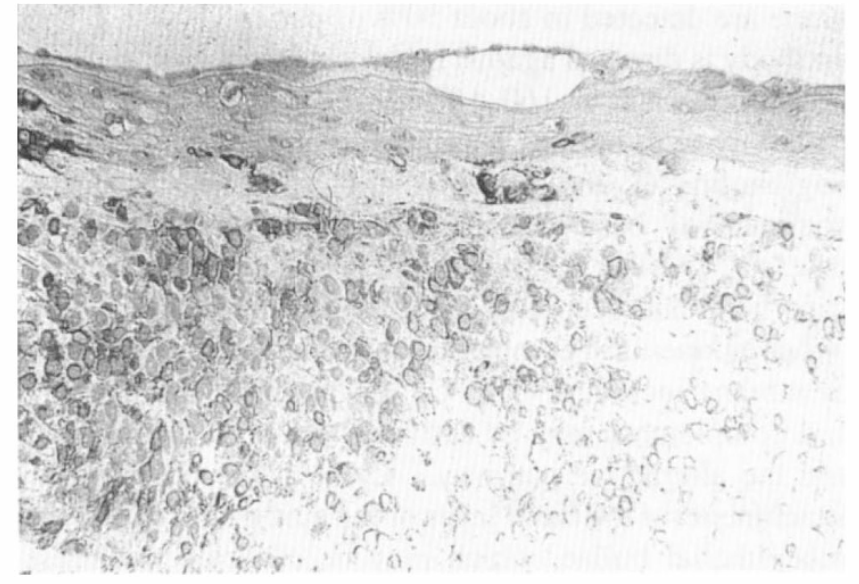

Fig. 3. Chronic ocular cicatricial pemphigoid stromal conjunctiva showing CD4+ T-cell infiltration. $\times 312$. (Courtesy of $\mathrm{Dr}$ W. Bernauer.)

changes in acute disease are characterised by a marked infiltration of neutrophils (Fig. 1), macrophages, Langerhans/dendritic cells and $\mathrm{T}$ lymphocytes compared with normal controls. In addition, there is significantly increased expression of the major histocompatibility class II antigen (HLA-DR), there are equal numbers of CD4+ and CD8+ T-cells and 4-10\% of the T-cells stain positive for interleukin 2 receptor, suggesting that they are activated $^{33,40,44}$ (Fig. 2). Staining for transforming growth factor-beta (TGF- $\beta$ ) is significantly increased.

The subacute phase of the disease is histologically similar to acute disease although the CD4+/CD8+ ratio drops to 0.4 . The chronic phase is characterised by an infiltration with T lymphocytes (Fig. 3), HLA-DR expressing cells and macrophages which are mildly increased in number. The $\mathrm{CD} 4+/ \mathrm{CD} 8+$ ratio is $0.5 .^{33}$ Mild to severe subepithelial fibrosis may be found in any of the three clinical phases.

For the conjunctival epithelium, the acute disease reveals marked infiltration with neutrophils and Langerhans cells. In chronic disease there is a similar cell profile to normal conjunctiva. T-cell infiltrate and upregulation of HLA-DR expression are not a feature of the epithelial disease. The epithelium may become thickened, metaplastic and may keratinise at any phase. Overall, the population of B-cells and plasma cells is no different to normal conjunctival epithelium or stroma at any stage of the disease. ${ }^{33}$

Fibrosis results from the stimulation of fibroblasts, often by fibrogenic growth factors. When quiescent fibroblasts are stimulated to proliferate by these modulators, there is transient expression of proto-oncogenes, including c-fos, c-myc and c-myb. These are a series of genes that are transducers of external growth factors and probably trigger the activation of genes that are required for proliferation. ${ }^{46}$ Experimentally, c-fos and c-myc are expressed after application of TGF- $\beta$, platelet-derived growth factor (PDGF), tumour necrosis factor (TNF) and interleukin 1 (IL-1) ${ }^{46,47,54}$ Conjunctival fibroblasts from patients with active cicatricial pemphigoid express c-myc in vitro. ${ }^{48}$ This suggests that these fibroblasts have been stimulated with a growth factor similar to the effect produced by TGF- $\beta$, PDGF, TNF or IL- 1 . This is consistent with immunohistochemical findings of raised levels of TGF- $\beta$ in acute disease and of TGF- $\beta$, PDGF and fibroblast growth factor in subacute OCP. ${ }^{33}$ The origin of these fibrogenic cytokines is unknown, but it is probable that they are produced by both acute and chronic inflammatory cell types.

\section{CLINICAL RESPONSE TO SYSTEMIC DRUGS}

Further insight into the mechanisms involved in fibrosis can be gleaned from the response to various drug treatments in OCP. Both dapsone ${ }^{25,37,49,50}$ and cyclophosphamide $e^{25,29,50}$ have been shown to reduce inflammation and impair or halt the progression of the fibrosis compared with untreated controls.

Dapsone is a sulphone and both inhibits the myeloperoxidase in polymorphonuclear leucocytes and stabilises lysosomal membranes. This reduces the release of lysosomal enzymes. ${ }^{51}$ It also suppresses migration of neutrophils to extravascular sites through inhibition of the adhesion required for neutrophil recruitment. ${ }^{52}$ Therefore, a response to dapsone is mainly due to inhibition of neutrophil recruitment and function.

Moderate doses of cyclophosphamide suppress both B-cell and CD4+ and CD8+ T-cells. This leads to a suppression of both T-cell-mediated and humoral responses. ${ }^{53}$ Therefore fibrosis may be inhibited by suppressing any or all of these cell lines. This points to a complex set of mechanisms that are involved in the aetiology of the fibrosis in OCP. This is further complicated by the number of growth factors demonstrated by immunohistochemistry. ${ }^{33}$ Further research is necessary to dissect in detail the mechanisms of cicatrisation in these inflammatory processes. This would be expected to lead to much more effective therapeutic regimes that may have fewer systemic side effects.

The authors are thankful to Dr W. Bernauer for his permission to include his work in this paper.

Key words: T-cells, Cicatricial pemphigoid, Conjunctiva, Fibrogenic cytokines, HLA-DR.

\section{REFERENCES}

1. Wright P. Cicatrizing conjunctivitis. Trans Ophthalmol Soc UK 1986;105:1-17.

2. Hall RP. The pathogenesis of dermatitis herpetiformis: recent advances. J Am Acad Dermatol 1987;16:1129-44.

3. Moschella SL, Pillsbury DM, Hurley HJ. Dermatology. Vol. 1. Philadelphia: WB Saunders, 1975:460-76.

4. Gruis NA, Bavinck JN, Steijlen PM, Schroeff JG van der, Haeringen A van, Happle R et al. Genetic linkage between the collagen VII (COL7A1) gene and the autosomal dominant form of dystrophic epidermolysis bullosa in two Dutch kindreds. J Invest Dermatol 1992;99:528-30.

5. Mooney E, Falk RJ, Gammon WR. Studies on complement deposits in epidermolysis bullosa acquisita and bullous pemphigoid. Arch Dermatol 1992;128:58-60.

6. McDonnell PJ, Schofield OM, Spalton DJ, Eady RA. Eye involvement in junctional epidermolysis bullosa. Arch Ophthalmol 1989;107:1635-7.

7. Richter HH, McNutt S. The spectrum of epidermolysis bullosa acquisita. Arch Dermatol 1979;115:1325-8. 
8. Woodley DT, Briggaman RA, O'Keefe EJ, Inman AO, Queen LL, Gammon WR. Identification of the skin basement-membrane autoantigen in epidermolysis acquisita. $\mathrm{N}$ Engl J Med 1984;310:1007-13.

9. Yancey KB, Lawley TJ. The immunology of the skin. In: Middleton E, Reed CE, Ellis EF, editors. Allergy: principles and practice. St Louis: Mosby, 1988:206-23.

10. Zierhut M, Theil HJ, Weidle EG, Steudhl KP, Sonnichsen K, Schaumburg-Lever G. Ocular involvement in epidermolysis bullosa acquisita. Arch Ophthalmol 1989;107:398-401.

11. Bean SF, Halubar K, Gillett RB. Pemphigus involving the eyes. Arch Dermatol 1975;111:1484-6.

12. Grando SA, Terman AK, Stupina AS, Glukhenky BT, Romanenko AB. Ultrastructural study of clinically uninvolved skin of patients with pemphigus vulgaris. Clin Exp Dermatol 1991;16:359-63.

13. Judd K, Lever W. Correlation of antibodies in skin and serum with disease severity in pemphigus. Arch Dermatol 1979;115:428-32.

14. Kaplan R, Callen J. Pemphigus associated diseases and induced pemphigus. Clin Dermatol 1983;1:42-71.

15. Korman N. Pemphigus. J Am Acad Dermatol 1988;18:1219-38.

16. Moy R, Jordan R. Immunopathology in pemphigus. Clin Dermatol 1983;1:72-83.

17. Venning V, Frith P, Bron A, Millard P, Wojnarowska F. Mucosal involvement in bullous and cicatricial pemphigoid: a clinical and immunopathological study. Br J Dermatol 1988;118:7-15.

18. Fine JD, Neises GR, Katz SI. Immunofluorescence and immunoelectron microscope studies in cicatricial pemphigoid. J Invest Dermatol 1984;82:39-43.

19. Zillikens D, Ambach A, Schuessler M, Dummer R, Hartmann AA, Burg G. The interleukin-2 receptor in lesions and serum of bullous pemphigoid. Arch Dermatol Res 1992;284:141-5.

20. Stanley JR. Bullous pemphigoid. In: Jegasothy BV, Lazarus GS, editors. Symposium on blistering disease. Dermatologic clinics. Philadelphia: WB Saunders, 1983:205-16.

21. Stanley JR, Woodley D, Katz S. Identification and partial characterisation of pemphigoid antigen extracted from normal human skin. J Invest Dermatol 1984;82:108-11.

22. Regnier M, Vaigot P, Michel S, Prunieras M. Location of bullous pemphigoid antigen in isolated human keratinocytes. J Invest Dermatol 1985;85:187-90.

23. Hardy KM, Perry HO, Pingree GC. Benign mucous membrane pemphigoid. Arch Dermatol 1971;104:467-75.

24. Foster CS, Wilson LA, Ekins MB. Immunosuppressive therapy for progressive ocular cicatricial pemphigoid. Ophthalmology 1982;89:340-53.

25. Foster CS. Cicatricial pemphigoid. Trans Am Ophthalmol soc 1986;84:527-663.

26. Mondino BJ, Brown SI. Ocular cicatricial pemphigoid. Ophthalmology 1981;88:95-100.

27. Lever WF. Pemphigus and pemphigoid: a review of theadvances made since 1964. J Am Acad Dermatol 1979;1:2-31.

28. Ahmed AR, Foster S, Zaltas M, Notani G, Awdeh Z, Alper CA, Yunis EJ. Association of DQw7 (DQB1*0301) withocular cicatricial pemphigoid. Proc Natl Acad Sci USA 1991;88:11579-82.

29. Mondino BJ. Cicatricial pemphigoid and erythema multiforme. Ophthalmology 1990;97:939-52.

30. Mondino BJ, Brown SI, Rabin BS. Autoimmune phenomenon of the external eye. Trans Am Acad Ophthalmol 1978;85:801.

31. Mondino BJ, Brown SI, Lempert S, Jenkins MS. The acute manifestations of ocular cicatricial pemphigoid: diagnosis and treatment. Ophthalmology 1979;86:543-52.

32. Mondino BJ, Ross AN, Rabin BS, Brown SI. Autoimmune phenomena inocular cicatricial pemphigoid. Am J Ophthalmol 1977;83:443-50.

33. Bernauer W, Wright P, Dart JKG, Leonard JN, Lightman S. The conjunctiva in acute and chronic mucous membrane pemphigoid: an immunohistochemical analysis. Ophthalmology 1993;100:339-46.

34. Dabelsteen E, Ullman S, Thomsen K. Demonstration of basement membrane autoantibodies in patients with benign mucous membrane pemphigoid. Acta Derm Venereol 1974;54:189-92.

35. Franklin RM, Fitzmorris CT. Antibodies against conjunctival basement membrane zone. Arch Ophthalmol 1983;101:1611-13.

36. Leonard JN, Hobday CM, Haffenden GP. Immunofluorescent studies in ocular cicatricial pemphigoid. Br J Dermatol 1988;118:209-17.

37. Person JR, Rogers RS III. Bullous and cicatricial pemphigoid: clinical, histopathologic, and immunopathologic correlations. Mayo Clin Proc 1977;52:54-66.

38. Waltman SR, Yarian D. Circulating autoantibodies in ocular pemphigoid. Am J Ophthalmol 1974;77:891-94.

39. Niimi Y, Zhu XJ, Bystryn JC. Identification of cicatricial pemphigoid antigens. Arch Dermatol 1992;128:54-7.

40. Rice BA, Foster CS. Immunopathology of cicatricial pemphigoid affecting the conjunctiva. Ophthalmology 1990;97:1476-83.

41. Jordan RE, Schroeter AL, Good RA. The complement system in bullous pemphigoid. II. Immunofluorescent evidence for both classical and alternate-pathway activation. Clin Immunol Immunopathol 1975;3:307-14.

42. Holubar K, Wolff K, Konrad K. Ultrastructural localization of immunoglobulins in bullous pemphigoid skin. J Invest Dermatol 1975;64:220-27.

43. Diaz LA, Calvanico NJ, Tomasi TB. Bullous pemphigoid antigen: isolation from normal human skin. J Immunol 1977; 118:605-8.

44. Sacks EH, Wieczorek R, Jakobiec FA, Knowles DM. Lymphocytic subpopulations in the normal human conjunctiva: a monoclonal antibody study. Ophthalmology 1986;93: 1276-83.

45. Roat MI, Sossi G, Thoft RA. Hyperproliferation of conjunctival fibroblasts from patients with cicatricial pemphigoid. Arch Ophthalmol 1989;107:1064-7.

46. Liboiroat E, Pelosi E, Di Francesco P, Gallanari P, Petrini M, Sposi NM. The EL2 rat fibroblast line: differential effects of growth factors (EGF, PDGF, FGF, TPA and TGF- $\beta$ ) on cell proliferation and c-fos expression. Ann NY Acad Sci 1987;511:318-28.

47. Muller R, Bravo R, Burckhardt J, Curran T. Induction of c-fos gene and protein by growth factors precedes activation of c-myc. Nature 1984;312:716-20.

48. Hunt LE, Vergnes JP, Roat MI. Altered proto-oncogene expression by conjunctival fibroblasts in cicatricial pemphigoid. Invest Ophthalmol Vis Sci 1991;32(Suppl):938.

49. Rogers RS III, Seehafer JR, Perry HO. Treatment of cicatricial (benign mucous membrane) pemphigoid with dapsone. J Am Acad Dermatol 1982;6:215-23.

50. Tauber J, Jabbur N, Foster CS. Improved detection of disease progression in ocular cicatricial pemphigoid. Cornea 1992;11:446-51.

51. Lang PG. Sulfones and sulfonamides in dermatology today. J Am Acad Dermatol 1979;1:479-92.

52. Booth SA, Moody CE, Dahl MV, Herron MJ, Nelson RD. Dapsone suppresses integrin-mediated neutrophil adherence function. J Invest Dermatol 1992;98:135-40.

53. Gilman AG, Goodman LS, Rall TW, Murad F. The pharmacological basis of therapeutics. New York: Macmillan, 1985.

54. Lin JX, Vilcek J. Tumour necrosis factor and interleukin-1 cause a rapid and transient stimulation of c-fos and c-myc mRNA levels in human fibroblasts. J Biol Chem 1987; 262:11908-11. 